\title{
The Influence of Seasonality Factors on Hotel Occupancy in Jordan
}

\author{
HazimRyed alMomani* Ahmad Puad Mat Som \\ Faculty of Applied Social Sciences, Universiti Sultan ZainalAbidin, Terengganu, Malaysia
}

\begin{abstract}
Tourism in general is a highly competitive industry. In order to maintain its growth and survival in this aggressive environment, tourism sector ought to hold advantages over other competitors in the market. Such advantages are granted through providing various services that match and exceed customers' expectations and demands.In a related development, hotel occupancy rate isdependent upon tourism and affected byseasonality, which indicates fluctuations of demand and supply in the tourism industry. This article discusses the nature of seasonality, the principal factors driving the phenomenon and how they influence hotel occupancy rate particularly in Jordan. The concluding section outlines possible strategies which could be introduced in tourism destinations to mitigate seasonality in visitation and lengthen the season during which visitors arrive.
\end{abstract}

Keywords: Seasonality, Natural Factor, Institutional Factor, Hotel Occupancy, Jordan

DOI: $10.7176 /$ JTHS/57-02

Publication date:June $30^{\text {th }} 2021$

\section{Introduction}

Jordan is apopular tourist destination that attracts many tourists from around the globe. Thisisa result of having many tourist attractions as well historical sites that people travel to visit, admire, and enjoy. Perhaps the keyfactor of making Jordan a major destination is the political atmosphere and stability, in addition to its unique location in the Middle East. Further, it contains a diverse and natural beauty, ancient history with many civilizations who resided in Jordan over the course of history. Tourism is a major contributor tothe improvement of the economy in the country (more than 800 million USD annually). Tourism sector in Jordan isa top ranked sectorthat increases the country's national income, with tourism beingthe second largest private sector with regards to employmentand number onein terms of increasing the external cash flow in the country (MOTA, 2021).

Jordan, a place which has been long a fascination to travelers through history, remains to enchantthe new generation by its diverse mixture of both modernity and tradition. From the charming starkness of Wadi Rum (The Valley of Rum), to the busy city centre of the capital city Amman, and the magnificent ruins of the ancient civilizations once lived on its soil. Jordan is also a distinctivetourist destination that offers manyspectacular sights, captivating accommodations, and elegant cuisine. The country ishome to numerous wondersthat are guaranteed to leave visitors in awe. With itbecoming a leading destination in the Middle East, Jordan has experienced an emergence of luxury hotels in many cities including Amman, Petra, Aqaba and the Dead Sea (MOTA, 2021).

\section{Literature Review}

Tourism Seasonality

Tourism is defined as the movement of tourists from their permanent place of residence to other regions, whereas seasonalitycan be various influences that govern the demand for tourismwhich is a result of several factors. Researchers have divided (effects/influences) into different categories, including natural(climatic) factors such as the weather and climate and their impact on seasonality, particularly the difference and change of temperatures, hours of sunlight,snowfalls, rain season, etc.Institutional factors include the number of festivities and holidays (i.e., official and religious holidays).

It can be argued that tourism sector is one of the most unstable sectors due to its exposure to many internal and external complexities, asthe number of tourists which is critically affected by economic, political and social factors (terrorism for example), naturaldisasters (Tsunami) and/or seasonal ones (floods). These factors greatly impact tourism, the number of visitation and hotel occupancy rate, either negatively or positively (Witt \& Moutinho, (1989) , Higham \& Hinch, 2002 and Pegg, Patterson and Gariddo (2012), Alzboun (2008), and Hartman (1986) claim that seasonality is a main phenomenon that faces most of the tourism sectors worldwide, and is a motivating topic of research for academics, coming to identify the various factors that impact tourism demand.

\section{Natural Factor}

There is a consensus between scholars such as Katab(1998), Al Hawary(2001), Jang (2004), Kocand Altinay (2007), that climate isthe most crucialnatural factor, which can be an attraction for visitors.Elements, including clean air, sun, and the temperatureare important attractions in summer. While extreme cold, heavy rain, snow and fog obscuring the sun and high humidity are elements that pose major threats to tourism in winter.Chen and Tingzhen (2010),Koenig, Lewis and Bischoff (2005), Jang (2004), featuretourism activities that are mainly 
dependent on climate and/or weather and natural seasonality that is affecting the hostingcountries. The farther away from the equator, the larger the differences are, tropical climates that increase humidity significantlyaffect the number of tourists.

A study by Al-Jamalih (2006) discusses the topic of seasonal tourism in Jordan and identifies three main periods in which the number of tourists varies from year to year.From November to middle of December, the climate is inclined to moderation especially in Aqaba (south of Jordan) and the Jordan valley. The second period starts from the middle of March until the end of Mayand the climate is generally mild. The third period is concentrated in summer, frommiddle of June to the end of August, where large numbers of tourists especially from the surrounding Arab countries come to enjoy recreational tourism and moderate climate of Jordan.

It is contested that tourism industry differs from other sectors, in whichthe number of tourists increases at certain times of the year and decreases in different period (Ibrahim Bazazo, 2007). Jordan, in general, witnesses a clear instability in tourism, particularly in Petra, where the number of visitors significantly increases in spring and decreases in fall, and generally scarce during the remaining times, where climate plays the key factor inseasonality. In a related development, seasonality directly affects the quality and quantity of labor; the demand for labor increases and decreases (in the recession season). However, on the economic side, the wages of workers increase during the peak period and decrease in the recession, and institutes the so-called seasonal unemployment. These factors are indeed pose threats to tourism investments in the country.

\section{Institutional Factor - SocialandCultural}

According to Lim \& McAleer (2001), Abdal Karim (2002), Jang(2004), Koc and Al tinay (2007), the most vital institutional factors that are determinant of the seasonal tourism are: types of vacations, study holidays, labor laws and workers. If vacations are spread throughout the year, tourist demand will be distributed throughout the year. As a result, the season will be reduced to a number of regulations. Laws and regulations that state the time and the length of vacations(ranges from two weeks to four weeks and especially during summer) leads to an increased tourism flow in summer, while decreases in wintercausing seasonality. Therefore, there is anecessity to alter the categories of international tourism relatedto holidays such as tourism, sports, cultural tourism, museums visits, festivals, and tourist sites.

Manning and Powers (1984), Mathieson and Wall (1982), and Duro (2016), agree that tourist season has two dimensions: the first is the peak season, especially in summer, and the second is the season of inactivity. In the peak season, problems that are faced by the host communities and visitors increase, thus increasing the number of visitors, which in turn, leads to traffic congestion and congestion in tourist sites, an increase in the costs of community services, increasing prices, growing pressure on the infrastructure and rising crime rates. This needsextra services, such as tightening security by providing more security personnel and providing health facilities. These problems lead to the resentment of the hosting communities towards tourism activities.Mahmud (2011), ontourism sociology, examined the relationship between tourists and the host, the forms of meeting between them, and the social and cultural effects of tourism, and he intended at identifying the social relationship between visitors andhosts, and the social and cultural influence between both. Timothy (1998)argues that certain communities use facilities and tourist services in periods of recession, which helps preserve community identity and maintain traditions of the local communities.

Kushan, Abdullah(2001),state that negative effects of increased tourist traffic on a specific area need ecological and social recovery, via appropriate strategies such as variation of tourism products, dropping of prices, endorsing alternative products, encouraging events and festivals to increase tourism traffic. Shukri (2014), in his analytical study of the social and cultural dimensions of tourism activity in the host communities, discusses social and cultural effects of tourism, and the relationship between visitors and the host community. He further claimsthe most significant negative social and cultural effects of tourism were presented, including the increase of the demand for facilities,amenitiesand infrastructure, altering of customs and traditions. As for the positive effects,on the other hand, include an increase of the exchange of culture between the hosts and visitors, learning of new languages, andconserving cultural heritage.

\section{Political Factor}

Alsarayreh, Jawabreh and Helalat (2010)argue that internal and external tourism is greatly affected by the political atmosphere and/or political instability; wars, riots, terrorism, and coups are such events that lead to the decline of the tourist flow in any region. It also negatively fashions relationships between countries, which sometimes leads to apply limitations on travelers. Saarinen (2003), Omari, Ali, Mahmoud and Jawabreh (2015) agreed that unstable political environment resulted in seasonality in the Arab world. In general, revolutions and armed conflicts that began in 2011, which started in Tunisia and led to the change of regime, and then spread to Egypt, led to the overthrow of former President Mohammed Hosni Mubarak, then in Libya, Yemen and Syria. This in turn led to the spread of corruption, economic stagnation, poor living conditions and increased political, economic, and media restrictions. Jordan's tourism sector has been particularly affected by the political situations in the surrounding 
countries which triggered seasonality.

Osama Al-Faouri (2016) conducted a study on security and tourism stability in Jordan, and he found that the tourism sector in Jordan is very sensitive to the Arab region's conflicts, wars, the spread of crime and the complications of Syrian refugees, which is one of the biggest political challenges facing the tourism sector in Jordan. In addition, Alsarayreh, Jawabreh and Helalat (2010) claimed that wars and terrorism are vital enemies forinternal and external tourism, whichnegativelyaffect the tourism worldwide in general, as warsdemolished the tourist flow, not only within fighting sides, but also on borderingstates. For example, when the Gulf war started in 1991, tourism during that period cloggedentirely in Iraq, and in the neighboring states, including Jordan and Syria. Not to mention the destruction of ruins caused by wars, and the destruction of museums, infrastructures, and the destruction of attractive tourist sites, e.g., Baghdad archaeological museum, which was destroyed in 2003 during the invasion of Iraq.

\section{Economic Factor}

The tourism industry is considered to be the strongest and the fastest growing industry in the world, and there is no indication whatsoever to the declineof the sector. International tourism revenues rose from 2.4 billion Euros in 1950 to 506 billion Euros in 1998 to 1999. During the same period, tourism grew from 25.3 million tourists to 625 million tourists, and the industry has also created 200 million jobs and nearly 4.0 trillion Euros of GDP worldwide. Darwishand Al-Bashir (2017), Goran Luorluka (2014)state that prices of tourism services throughout the various seasons contribute to an upsurge or decline in the seasonal focus of tourism activities, that is, the economic effects are related to difficulties of extreme or petite use of tourism resources, as the pressure on them increases, which surpasses their capacity during the peak season, while the remaining hindered or working at short levels during the restof the year. This provoked investors to make twice as many efforts to preventdeficitsduring the recession season, by raising prices to the level that ensuresattaining the bare minimumearnings to covercosts. In addition, the temporary nature of tourismadverselyinfluences the amount of loyalty, association and dedication of employees, which influences the quality of standards. As for the social aspect, the economic factor is also correlated by escalating pressure on social absorbentcapabilities, which leads to the increase of social ills. Increasing the number of tourists during the peak seasonintensifies pressure on the infrastructure and the superstructure; the price increase negatively influences both the visitors and the hosts.

\section{Hotel Occupancy Rate}

Tang (2011), Abd Al Karim(2013), Haji and Abdullah (2015) suggest that hotel occupancy rate can be definedas the number of rooms occupied by tourists in proportion to the number of rooms available. It is the most vitalbenchmark for determining hotel demand, a significant indicator of hotel profits over a particular period of time that is influenced by the influx of visitors into the hosting country.Haji and Abdullah (2015) propose that hotel occupancy rate relies on the interior and exterior factors of the hotel. Exterior factors are characterized bythe policies, law, demography, wars and terrorism, while interior factors are rather defined as the internal regulations of the hotel itselfwith regard to the excellence of services, prices, quality of, and location.

Abd Al Karim(2013) suggests thathotel occupancy ratediffersduring the same year, the fluctuating demand being the reason for that. Hotel demand grows in summer; thus, peak season is generally in summer, whilst this rate declines through the other seasons. Seasonality, hence, preciselyaffects hotel occupancy rate. Management of the hotel should anticipateoccupancy rate; nonetheless, it is difficult to forecast the full occupancy rate,since the hotel sector is primarilyinfluenced by economic factors and internal and/or external policies. A report published in ZAD magazine(2011) reported the occupancy rate in the Jordanian capital city (Amman)slumpeddown 6\% in the first four months in 2011.This fall in hotel occupancy rate is not exclusive to Amman. Rather, the occupancy rates in the Middle East and Africa were 59 per cent compared to 65.3 per cent in the previous year, while hotels in Europe scored the top occupancy rate in the world, of about 65 per cent followed by Asia-Pacific with 64.8 per cent.

\section{Underpinning Theories Push-Pull Theory}

The aim of any given tourism attraction is to meet and satisfy the demands of the visitors. The movement of tourism could be affected by domestic or by external motives. In other words, people could be affected by push factors or by pull factors to make theirdetermination for travelling and deciding their destinations. According to Lee (1966) states that there are mainly four factors responsible for influencing migration, which can be stated as follows: i) factorsassociated with the place of source/origin, ii) factors relatedto the destination. Such factors (area of origin and destination) are assumed to be pull and push factors which behave either to draw the people to the destination or repel them, iii) factors associatedwith intervening barriers between the destination and the origin. And finally, individual/personal factors which influence the decisions of visitors.

Dann(1977) declared a strong relationship between push and pull factors. Push factors are aspirations, 
demands, and experiencesconcerningindividuals, while pullfactor are the targetdestination. Kim and Lee (2002)show that the mental motives could be escaping social pressure, leisure, or relaxation, going into adventures with social prestige being the motive, visiting friends and family members, self-esteem, exposure into new places and cultures, the wish for learning and novelty, orescapingbusy and loudareas to more quiet and peaceful corners of the world. They investigated the relationship between motives (push factors) and the destination attributes (pull factors). Thepopulation of their study consisted of leisure visitors travelling to South Korea to visit six national parks in the country.

Push and pull factors were measured on five-point Likert scale. The results of their analysis suggestclear relationship between pulland destination attributes (push factors).Similarly, Jonsson and Devonish (2008) executed a quantitative research design. Questionnaires were distributed to obtain the data on leisure tourist motives (push factors) and on destination attributes (pull factors). Theyspeculate that push factors are intangibleones that push tourists away from their original place of resident, whereas pull factors are the attributes of the target/destination that drawvisitors towardsthe destination. The attributes of the destination (pull factors) could entail natural or historic and cultural resources, or different activities and events, or could be a mixture of several attributes in a destination that match a variety of motives(Grimm and Needham, 2012; Kim and Lee, 2002; Kim et al., 2003; Klenosky, 2002; Nicolau and Mas, 2006).Uysal and Jurowski (1994) argue that there are internal forces which drive individuals to make their decision to visit a destination, and external motives which pull individuals to prefer a given destination. They also argue thatexternal forces are attributed to the attractiveness of the destination,mainlycombined with theanticipations and perceptions of tourists, e.g., the reputation of the required place (destination), gainexpectancy and novelty.

Chen and $\mathrm{Hsu}(2000)$ state that pull factors are relatedto travelers' perceived impression of the destination. Sinha (2000) claims that pull factors are more vital than push factors. Additionally, Kim et al. (2003) argue that escapingaffectstravelers' motivation (to travel or not), and the features and attributes of destinationsinfluence their decision of selecting the destination (where to go). Touristsmight want to escape from his/her atmosphere (i.e., to travel outside his/her resident environment) and pursuea different atmosphere. They identify three main pull factors from 12 attribute items, and four push factors from 12 attributes using a sample of leisure tourists visiting different national parks in South Korea. The pull factors included "keytourist resources", "information and convenience of facilities", and "accessibility and transportation". The results of the correlation analyses showed aclear relationship between push and pull factors. Therefore, a destination that has several significant tourism attractions might draw tourists who are willing to escape from their daily life routine, or find what they are seeking for in its natural, historical or modern tourist infrastructures. Pull factors, on the other hand, influence their choice to be part of the tourism trip. Hence, whether natural or man-made, they are indeedvital in attracting tourists.

\section{Conclusion}

Studies examined in this articlegenerallyrevealedthathotel occupancy rate can and is affected by many factors. It is apparent that certain tourists who are willing to travel have decided that, without any strategy, it was motivated bycertain circumstances surrounding them. This assumption remains vaguewith regard to hospitality, in which the adoption of climate and weather conditions and/or institutional factors(social, cultural, political, and economic)mightmotivate travelers to make their trips. Hence, the rate of tourists increases when the destination is considered to be stable; this of course is valid in countries that are considered to be worldwide attractions, and hotel occupancy rate grows by the flow of tourists into the destination. The relevant literature and studies regarding this topicsuggest that seasonality might sometimes be an advantage(beneficial) or a disadvantage(not beneficial). With this said, previous research and studies have illustrated that seasonality can have both advantages and disadvantages for the hosting countries. Currently, seasonality is evidently, an influential factor in the process of making a decision for traveling.Lastly, since tourism sector plays a major rule in the Jordanian economy, more research ought to be conducted, that would be of a great importance to the officials in Jordan, particularly, the Ministry of Tourism and Public Antiquities, in order to develop this sector for its great contribution to the country's economy.

\section{References}

Al-Hawary, MothanaTaha, (2001), the limited demand for tourism in Najaf province, causes and treatments, Journal of the Faculty of al MAMON the university.

Alzboun, N. (2018). Measuring Seasonality of Tourism Demand in Petra, Jordan (2006-2017). Modern AppliedScience, 12(9), 131.doi:10.5539/mas.v12n9p131. Retrieved from, https://www.researchgate.net/publication/327141509.

Aram Abdel Karim.(2013). Percentage of hotel occupancy wit application to the Iraqi hotel industry for the period 2002-2007. Journal of Baghdad College of Economic Sciences, (35), 67-92, Retrieved from, https://www.iasj.net/iasj/article/79090.

BarOn, R. R. V. (1975). Seasonality in tourism: a guide to the analysis of seasonality and trends for policy making. 
London: Economist Unit. Intelligence Retrieved https://journals.sagepub.com/doi/abs/10.1177/004728757601400470.

Chen, J. S., \& Hsu, C.H. (2000). Measurement of Korean tourists' perceived images of overseas destinations. Journal of Travel Research, 38(4), 411-416. Retrieved from, https://journals.sagepub.com/doi/abs/10.1177/004728750003800410.

Chen, T. (2010). Asian tourism seasonality, with an emphasis on China's Golden Week system (Doctoral dissertation, James Cook University). Retrieved from, https:/www.researchonline.jcu.edu.au/19000/.

Dann, G. M. S. (1977). Anomie, ego-enhancement and tourism. Annals of Tourism Research, 4(4), $184-194$. Retrieved from, https://www.sciencedirect.com/science/article/abs/pii/0160738377900378.

Dann, G. M. (1977). Anomie, ego-enhancement and tourism. Annals of tourism research, 4(4), 184-194. Retrieved from, https://www.sciencedirect.com /science/article/abs/pii/0160738377900378.

Duro, J. A. (2016). Seasonality of hotel demand in the main Spanish provinces: Measurements and decomposition exercises. Tourism Management, 52, 52-63.doi:10.1016/j.tourman.2015.06.013, Retrieved from. https://www.sciencedirect.com/science/article/abs/pii/S0261517715001375.

Edrees Ramadhan Haji (2015).The seasonal impact on the tourist market and supply demand. Journal of Anbar University for Economic and Administrative Sciences, 7(14), 454-474.,Resort Shaklawa model. Retrieved from, https://www.researchgate.net/publication/326439508.

Grimm, K. E., \&Needham, M. D. (2012). Moving beyond the in motivation: attributes and perceptions of conservation volunteer tourists.Journal of travel research, 51(4), 488-50. Retrieved from, https://journals.sagepub.com/doi/abs/10.1177/0047287511418367

Hartmann, R. (1986). Tourism, seasonality and social change, Leisure Studies. 5(1), 25-33. Retrieved from, https://www.tandfonline.com/doi/abs/10.1080/02614368600390021.

Higham, J., \&Hinch, T. (2002). Tourism, sport and seasons: the challenges and potential of overcoming seasonality in the sport and tourism sectors. Tourism Management,23(2),175-185. Retrieved from, http://bestprojectjo.org/sites/default/files/MICE\%20Strategy.pdf.

Ibrahim Bazazo(2007), Seasonal Phenomenon in Petra Region, Alrae newspaper, 25/4/2007, Retrieved from, http://webcache.googleusercontent.com/search.

Jang, S. (Shawn). (2004). Mitigating tourism seasonality. Annals of Tourism Research, 31(4), 819836.doi:10.1016/j.annals.2004.02.007. Retrieved from, https://www.sciencedirect.com/science/article/abs/pii/S0160738304000672.

Jönsson, C., \& Devonish, D. (2008). Does nationality, gender, and age affect travel motivation? A case of visitors to the Caribbean island of Barbados. Journal of Travel \& Tourism Marketing, 25(3-4), 398-408. Retrieved from, https://www.tandfonline.com/doi/full/10.1080/10548400802508499.

Katap, Niyaz Abdul Aziz, (1988) tourist assessment of the climate of the Kurdistan region of Iraq, Master of Geography, Faculty of Arts, University of Salahalddin.

Kim, S., \& Yoon, Y. (2003). The Hierarchical Effects of Affective and Cognitive Components on Tourism Destination Image. Journal of Travel\& Tourism Marketing, 14(2), 1-22. Retrieved from, https://www.tandfonline.com/doi/abs/10.1300/J073v14n02_01.

Kim, S., \&Lee, C. (2002). Push and pull relationships. Annals of tourism research. Annals of Tourism Research, Vol. 29, No. 1, pp. 257-260, 2002, 2001 Elsevier Science Ltd. All rights reserved. Printed in Great Britain $0160-7383 / 01 / \$ 22.00$.

Kim, S., Lee, C., \&Klenosky, D.B. (2003).The influence of push and pull factors at Korean national parks. Tourism management, 24(2), 169-180. Retrieved from, https://www.sciencedirect.com/science/article/abs/pii/S0261517702000596.

Klenosky, D. B. (2002). The"pull" of tourism destinations: A means-end investigation. Journal of Travel Research, 40(4), 385-395. Retrieved from, https://journals.sagepub.com/doi/abs/10.1177/004728750204000405.

Koc, E., \&Altinay, G. (2007).An analysis of seasonality in monthly per person tourist spending in Turkish inbound tourism from a market segmentation perspective. Tourism management, 28(1), 227-237. Retrieved from , https://www.sciencedirect.com/science/article/abs/pii/S0261517706000069.

Koenig - Lewis, N., \& Bischoff, E. E. (2005). Seasonality research: The state of the art. International Journal of Tourism Research, 7(4-5), 201-219. Retrieved from, https://onlinelibrary.wiley.com/doi/abs/10.1002/jtr.531.

Kushan, Abdullah(2001), Urban Development and its Impact on Tourism Demand Development, Field Study in Baghdad City, Master Thesis.

Lee, E. (1966). A theory of migration. Demography, 3(1), 47-57. Retrieved from, https://link.springer.com/article/10.2307/2060063.

Li, X., Pan, B., Smith, W.W., \&Zhang, L. (2008). Baseline and enhanced image: the effect of online information search. Paper presented at travel and tourism research association conference,1-6. Retrieved from, https://www.researchgate.net/publication/255711431_Baseline_and_Enhanced_Image_The_Effect_of_Onli 
ne_Information_Search.

Lim, C., \&McAleer, M. (2001). Monthly seasonal variations. Annals of Tourism Research, 28(1), 6882.doi:10.1016/s0160-7383(00)00002-5.Retrieved https://www.sciencedirect.com/science/article/abs/pii/S0160738300000025.

Manning, R. E., \& Powers, L. A. (1984). Peak and off-peak use: redistributing the outdoor recreation/tourism load. Journal of Travel Research, 23(2), 25-31, Retrieved from, https://journals.sagepub.com/doi/abs/10.1177/004728758402300204.

Mathieson, A., \& Wall, G. (1982). Tourism, economic, physical and social impacts. Longman, Retrieved from https://www.cabdirect.org/cabdirect/abstract/19831895928.

MOTA (2021).Ministry of Tourism and Antiquities. Retrieved from, https://www.mota.gov.jo/Ar/Pages/\%D8\%AA\%D8\%B9\%D8\%B1\%D9\%91\%D9\%81_\%D8\%B9\%D9\%84 $\% \mathrm{D} 9 \% 89 \% \mathrm{D} 8 \% \mathrm{~A} 7 \% \mathrm{D} 9 \% 84 \% \mathrm{D} 8 \% \mathrm{~A} 7 \% \mathrm{D} 8 \% \mathrm{~B} 1 \% \mathrm{D} 8 \% \mathrm{AF} \% \mathrm{D} \% \% 86$.

Nicolau, J. L., \& Mas, F.J. (2006). The influence of distance and prices on the choice of tourist destinations: The moderating role of motivations. Tourism Management, 27(5), 982-996. Retrieved from, https://www.sciencedirect.com/science/article/abs/pii/S0261517705001652.

Osama al-Faouri(2016), The most Important Challenges Facing the Jordanian Tourism sector, Published Date 17/8/2016, Alrai newspaper, Retrieved from, http://alrai.com/article/1006691.

Pegg, S., Patterson, I., \&Gariddo, P. V. (2012). The impact of seasonality on tourism and hospitality operations in the alpine region of New South Wales, Australia. International Journal of Hospitality Management, 31(3), 659-666, Retrieved from, https://www.sciencedirect.com,/science/article/abs/pii/S0278431911001459.

Saarinen, J. (2003). The Regional Economics of Tourism in Northern Finland: The Socio-economic Implications of Recent Tourism Development and Future Possibilities for Regional Development. Scandinavian Journal of Hospitality andTourism,3(2),91113, Retrievedfrom, https://www.tandfonline.com/doi/abs/10.1080/15022250310001927.

Sinha, S. (2002). International tourism in developing nations: an empirical study. Unpublished doctoral dissertation, university of north Texas. Retrieved http://citeseerx.ist.psu.edu/viewdoc/download?doi=10.1.1.468.8763\&rep=rep1\&type=pdf.

Tang, C. M. F. (2011). Hotel occupancy rate volatility and its determinants, (Doctoral dissertation, Victoria University). Retrieved from https://vuir.vu.edu.au/21348/.

Timothy, D. J. (1998).Cooperative tourism planning in a developing destination. Journal of Sustainable Tourism, 6(1), 52-68 Retrieved from, https://www.tandfonline.com/doi/abs/10.1080/09669589808667301.

United Nation World Tourism Organization (2009). Tourism highlights. Retrieved from , http://www.mbatourism.gr /unwto_highlights09_en_lr.pdf.

United Nation World Tourism Organization. (2011). International-tourism-maintains momentum-despitechallenges. Retrieved from, Http://www.media.unwto.org/en/pressrelease.

Uysal, M., \&Jurowski, C. (1994). Testing the push and pull factors. Annals of tourism research, 21, 844-846. Retrieved from, https://www.sciencedirect.com/science/article/abs/pii/0160738394900914.

Witt, S. F., \& Moutinho, L. (1989). Tourism marketing and management handbook. Prentice Hall. Retrieved from, https://www.cabdirect.org/cabdirect/abstract/19891869663.

Zad magazine (2011), Hotel occupancy in Amman declined. Retrieved from. http://www.jordanzad.com/print.php?id=45597. 